\title{
PENGARUH MODEL ADVANCE ORGANIZER DENGAN PETA KONSEP TERHADAP SIKAP SISWA SMP DALAM PEMBELAJARAN MATEMATIKA
}

\author{
Mellawaty \\ Universitas Wiralodra, Jalan Ir. H. Juanda KM.3 Indramayu, mellatristiana78@gmail.com
}

\begin{abstract}
ABSTRAK
Sikap siswa merupakan salah satu fokus pada proses pembelajaran. Akan tetapi pada kenyataannya masih kita jumpai siswa yang sikapnya masih negatif terhadap mata pelajaran matematika. Salah satu alternatif pembelajaran yang dapat membuat siswa bersikap positif terhadap mata pelajaran matematika adalah model Advance Organizer dengan peta konsep. Penelitian ini bertujuan untuk mengetahui sikap siswa yang memperoleh pembelajaran model Advance Organizer dengan peta konsep dan siswa yang memperoleh pembelajaran metode ekspositori. Penelitian ini menggunakan metode eksperimen. Populasi dalam penelitian ini adalah siswa kelas VII SMP Negeri 1 Kroya Kabupaten Indramayu dan diambil dua kelas secara acak menurut kelas sebagai sampel. Instrumen yang digunakan dalam penelitian ini adalah non-tes. Berdasarkan analisis data hasil penelitian, diperoleh kesimpulan bahwa, sikap siswa positif terhadap penggunaan model Advance Organizer dengan peta konsep dalam pembelajaran matematika.
\end{abstract}

Kata Kunci : Advance Organizer, Peta Konsep, Sikap.

\begin{abstract}
Attitude is one focus of learned process. But in reality they have a negative certain attitude to mathematics attented clases. One alternative learning that can improve attitude students is a model Advance Organizer with a concept map. This study aims to determine the increase in mathematics attitude of students who received Advance Organizer model learning with concept maps and students who obtain teaching expository method. This study used an experimental method. The population in this study were students of class VII SMP Negeri 1 Kroya Indramayu and taken two classes at random according to the class as a sample. Instruments used in this research is non-test. Based on the analysis of research data, we concluded that, by enhancing the mathematics attitude of students who obtain a mathematical model study Advance Organizer to map the concept positive than students who received learning expository method.
\end{abstract}

Keywords: Advance Organizer, Concept Map, Attitude.

How to Cite: Mellawaty. (2017). Pengaruh Model Advance Organizer dengan Peta Konsep Terhadap Sikap Siswa SMP dalam Pembelajaran Matematika. Mathline: Jurnal Matematika dan Pendidikan Matematika, Vol.2, No.1, 81-90.

\section{PENDAHULUAN}

Istilah "mathematics" (Inggris) berasal dari istilah latin "mathematica" yang awalnya dari istilah Yunani "mathematike" yang berarti relating to learning (Sutrisno, 2011). Definisi pembelajaran matematika menurut Depdiknas (Sutrisno, 2011) adalah "sebagai suatu sistem atau proses membelajarkan subjek didik yang di rencanakan atau di 
desain, dilaksanakan, dan dievaluasi secara sistematis agar subjek didik dapat mencapai tujuan-tujuan pembelajaran yang efektif dan efisien".

Dalam pembelajaran dikenal istilah strategi, pendekatan, metode, dan model pembelajaran yang dapat digunakan agar siswa lebih mudah memahami dan meningkatkan kemampuan berpikirnya dalam matematika. Adapun pengertian masing-masing istilah tersebut menurut Suherman (2001) adalah:

1. Strategi pembelajaran adalah siasat atau kiat yang sengaja direncanakan guru berkenaan dengan segala persiapan pembelajaran agar pelaksanaan pembelajaran berjalan dengan lancar dan tujuan berupa hasil belajar dapat tercapai secara optimal.

2. Pendekatan pembelajaran adalah cara yang ditempuh guru dalam pelaksanaan pembelajaran agar konsep yang disajikan dapat diadaptasikan oleh siswa.

3. Metode pembelajaran adalah cara menyajikan materi yang masih bersifat umum, misalnya seorang guru menyajikan materi dengan penyampaian dominan secara lisan dan sekali-kali ada tanya jawab.

4. Model pembelajaran adalah pola interaksi siswa dengan guru di dalam kelas yang menyangkut strategi, pendekatan, metode, dan teknik pembelajaran yang diterapkan dalam pelaksanaan kegiatan belajar mengajar di kelas.

Matematika sebagai salah satu disiplin ilmu merupakan ilmu pengetahuan yang sangat penting untuk dipelajari, pernyataan ini sejalan dengan pendapat Cockroft (Widiastuti, 2010),

Matematika perlu diajarkan kepada siswa karena (1) selalu digunakan dalam segala segi kehidupan; (2) Semua bidang studi memerlukan keterampilan matematika yang sesuai; (3) Merupakan sarana komunikasi yang kuat, singkat dan jelas; (4) Dapat digunakan untuk menyajikan informasi dalam berbagai cara; (5) Meningkatkan kemampuan berfikir logis, ketelitian dan kesadaran keruangan; (6)

Memberikan kepuasan terhadap usaha memecahkan masalah yang menantang.

Ruseffendi (2006) menyatakan, "Kita harus menyadari bahwa matematika itu sangat penting baik sebagai alat bantu, sebagai ilmu (bagi ilmiyawan), sebagai pembimbing pola pikir, maupun sebagai pembentuk sikap". Mengingat pentingnya matematika baik bagi ilmu pengetahuan maupun dalam kehidupan sehari-hari, maka matematika harus dikuasai oleh masyarakat terutama bagi para pelajar yang merupakan generasi muda.

Pada tingkat pertama dalam belajar, informasi dapat dikomunikasikan pada siswa baik dalam bentuk belajar penerimaan yang menyajikan informasi itu dalam bentuk final, 
maupun dengan bentuk belajar penemuan yang mengharuskan siswa untuk menemukan sendiri sebagian atau seluruh materi yang akan diajarkan. Pada tingkat kedua dalam belajar, siswa menghubungkan atau mengaitkan informasi itu dengan pengetahuan (berupa konsep - konsep atau lain - lain) yang telah dimilikinya. Belajar bermakna dapat terjadi jika siswa menghubungkan informasi yang baru diterimanya dengan konsep yang telah ada dalam struktur kognitifnya.

Sebaliknya apabila siswa hanya mencoba-coba menghafalkan informasi yang baru diterima tanpa menghubungkannya dengan konsep-konsep yang telah ada dalam struktur kognitifnya maka terjadilah apa yang disebut dengan belajar hafalan. Belajar matematika tidak hanya cukup dengan menghafal, justru yang dituntut adalah kemampuan menghubungkan konsep-konsep yang telah dipelajarinya sehingga pembelajaran matematika menjadi bermakna.

Menurut Ausubel (Dahar, 2011) belajar bermakna merupakan suatu proses dikaitkannya informasi baru pada konsep-konsep yang relevan yang terdapat dalam struktur kognitif seseorang. Dahar (2011) menyatakan bahwa faktor-faktor utama yang mempengaruhi belajar bermakna menurut Ausubel ialah struktur yang ada, stabilitas, dan kejelasan pengetahuan dalam suatu bidang studi tertentu dan pada waktu tertentu.

Ausubel (Ruseffendi, 2006) membedakan belajar menghafal dengan belajar bermakna. Belajar menghafal ialah belajar melalui menghafalkan apa yang sudah diperoleh, sedangkan belajar bermakna ialah belajar yang untuk memahami apa yang sudah diperolehnya itu dikaitkan dengan keadaan lain sehingga belajarnya itu lebih mengerti. Misalnya siswa belajar perkalian fakta dasar, 5 × 6 misalnya, bisa dengan jalan menghafal. Tetapi ia bisa juga mengaitkan 5 x 6 itu dengan sebuah jajaran yang terdiri dari 5 baris dan 6 kolom sehingga ia mengerti arti 5 x 6 itu. 
Menurut Ausubel (Dahar, 2011) belajar dapat diklasifikasikan ke dalam dua dimensi. Dimensi pertama berhubungan dengan cara informasi atau materi pelajaran yang disajikan pada siswa melalui penerimaan atau penemuan. Dimensi kedua menyangkut cara bagaimana siswa dapat mengaitkan informasi itu pada struktur kognitif yang telah ada. Struktur kognitif adalah fakta, konsep, dan generalisasi yang telah dipelajari dan diingat oleh siswa.

Konsep matematika tersusun secara hierarkis, artinya dalam mempelajari matematika, pemahaman konsep sebelumnya menjadi prasyarat untuk dapat memahami konsep selanjutnya. Oleh karena itu penyajian materi dalam matematika harus benar-benar diperhatikan. Dalam hal ini peran guru sebagai seorang pendidik sangat penting dalam mendukung keberhasilan belajar siswa. Gintings (2008) menyatakan, "Pada hakekatnya inti dari proses pendidikan adalah belajar dan pembelajaran dalam mana guru berperan selaku sutradara, aktor, manajer dan sekaligus merangkap sebagai penilai”.

Keberhasilan proses belajar mengajar dapat dilihat dari keberhasilan siswa yang mengikuti kegiatan pembelajaran, yaitu dari tingkat pemahaman, penguasaan materi, kemampuan pemecahan masalah siswa, dan sikap siswa terhadap proses belajar mengajar tersebut. Semakin tinggi kemampuan pemahaman, penguasaan materi, kemampuan pemecahan masalah siswa, dan sikapnya lebih positif, semakin tinggi pula tingkat keberhasilan pembelajaran. Banyak faktor yang mempengaruhi keberhasilan belajar siswa sebagaimana dinyatakan oleh Ruseffendi (2006),

Terdapat beberapa faktor yang dapat mempengaruhi keberhasilan siswa belajar. Faktor-faktor yang hampir sepenuhnya tergantung pada murid antara lain: kecerdasan anak, kesiapan anak, dan bakat anak. Sedangkan faktor yang tergantung pada guru antara lain: kemampuan (kompetensi), suasana belajar dan kepribadian guru sebagai manusia model. Dan satu faktor lain di luar kemampuan murid maupun guru, yaitu kondisi masyarakat.

Siswa membutuhkan pengalaman dan latihan dalam merumuskan masalah sebagaimana halnya dalam memecahkan masalah, mereka harus mengetahui berbagai macam strategi pemecahan masalah serta mengetahui strategi mana yang berguna dalam menyelesaikan permasalahan tersebut. Ketika menghadapi suatu permasalahan, siswa harus mampu memformulasikan masalah tersebut, memilih informasi-informasi yang 
relevan dengan masalah tersebut, serta mengetahui bagaimana cara dan strategi yang harus dipilih untuk diterapkan dalam memecahkan masalah tersebut.

Berkaitan dengan hal tersebut, terdapat suatu model pembelajaran konstruktivistik yang dapat dikatakan mirip dengan model tradisional dalam konteks metode penyampaian materi, yaitu model pembelajaran Advance Organizer. Model Advance Organizer ini diilhami oleh teori belajar bermakna (meaningful learning) dari David Ausubel. Meskipun metode penyampaian materinya melalui ceramah, pembelajaran Advance Organizer dapat mencapai kebermaknaan dalam pembelajaran. Pemilihan penggunaan model Advance Organizer karena dalam pelaksanaannya dapat meningkatkan struktur kognitif siswa.

Model pembelajaran Advance Organizer merupakan model pembelajaran yang diciptakan oleh David Ausubel pada tahun 1960-an. Model pembelajaran Advance Organizer mengarahkan pada siswa ke materi yang akan mereka pelajari dan menolong mereka untuk mengingat kembali informasi yang berhubungan yang dapat digunakan dalam membantu menanamkan pengetahuan baru.

Namun demikian, Ausubel belum menentukan cara yang sesuai yang dapat digunakan guru untuk mengetahui apa yang telah diketahui oleh siswa. Dahar (2011) menyatakan bahwa berkenan dengan hal ini, Novak dalam bukunya Learning How to Learn mengemukakan bahwa cara untuk mengetahui konsep-konsep yang telah dimiliki siswa dan agar belajar bermakna, dapat berlangsung dengan dilakukannya pertolongan peta konsep.

Menurut Dahar (2011) peta konsep dikembangkan untuk menggali ke dalam struktur kognitif pelajar dan untuk mengetahui, baik bagi pelajar maupun guru, melihat apa yang telah diketahui pelajar. Hudojo, dkk. (Supratman, 2009) menyimpulkan bahwa peta konsep itu merupakan jaringan konsep yang antara konsep-konsep tersebut dihubungkan dengan proposisi. Proposisi tersebut bias berupa kata: mempunyai, adalah, merupakan, terdiri dari, mengandung, berasal dari, yaitu, bersifat, jika...maka..., dll. Proposisi menunjukkan keterpaduan dalam jaringan tersebut.

Sikap berasal dari bahasa latin yaitu aptus yang diartikan sebagai kecenderungan untuk bertindak berkenaan dengan objek tertentu. Sikap secara umum dapat dikatakan sebagai perilaku seseorang. Dengan kata lain, sikap siswa diartikan sebagai prilaku yang ditunjukan oleh siswa selama berlangsungnnya pembelajaran. Menurut Sudjana (Herdian, 2010), “Ada tiga komponen sikap yakni: kognisi, berkenaan dengan pengetahuan seseorang tentang objek atau stimulus yang dihadapinya. Afeksi, berkenaan dengan 
perasaan dalam menghadapi objek tersebut. Konasi, berkenaan dengan kecenderungan berbuat terhadap objek tersebut". Oleh karena itu, sikap selalu bermakna bila dihadapkan kepada objek tertentu, misalnya sikap siswa terhadap mata pelajaran, sikap mahasiswa terhadap pendidikan matematika atau sikap guru terhadap profesinya.

Sikap merupakan suatu yang dipelajari, dan sikap menentukan bagaimana individu bereaksi terhadap situasi serta menentukan apa yang dicari individu dalam kehidupan. Sikap menurut Suherman \& Sukjaya (1990), "...berkenaan dengan perasaan (kata hati) dan manifestasinya berupa prilaku yang bersifat positif (favorable) atau negatif (unfavorable) terhadap obyek atau obyek-obyek tertentu".

Sedangkan menurut Syah (2007), "Dalam arti yang sempit sikap adalah pandangan atau kecenderungan mental". "Sikap (attitude) adalah kecenderungan yang relatif menetap untuk bereaksi dengan cara baik atau buruk terhadap orang atau barang tertentu" (Bruno dalam Syah, 2007). Dengan demikian, pada prinsipnya sikap itu dapat kita anggap suatu kecenderungan siswa untuk bertindak dengan cara tertentu (Syah, 2007).

Sikap siswa terhadap matematika masih rendah, walaupun begitu sikap tersebut dapat dibangun menjadi lebih baik. Berikut cara menumbuhkan sikap positif bagi siswa Menurut Ruseffendi (2006), Sikap positif bisa tumbuh bila:

1. Materi pelajaran diajarkan sesuai dengan kemampuan siswa; pada umumnya siswa akan sering memperoleh nilai baik.

2. Matematika yang diajarkan banyak kaitannya dengan kehidupan sehari-hari.

3. Siswa banyak berpartisipasi dalam reekreasi, permainan dan teka-teki matematika.

4. Soal-soal yang dikerjakan siswa, pekerjaan rumahmisalnya, tidak terlalu banyak, tidak terlalu sukar, dan tidak membosankan; berikan tugas-tugas untuk mengeksplorasi matematika, bukan mengerjakan soal-soal rutin.

5. Penyajian dan sikap guru menarik, dan dapat dorongan dari semua pihak. Penyajian pelajaran akan menarik siswa bila tepat dalam memilih materi ajar, strategi belajarmengajar, metode/teknik mengajar, dan media pengajaran. Sikap guru yang menarik dan dorongan dari luar, bisa dalam bentuk pengakuan dan pujian, baik dari guru, orang tua murid maupun temannya.

6. Evaluasi keberhasilan belajar siswa yang dilakukan guru, mendorong siswa untuk lebih tertarik belajar matematika, tidak sebaliknya, membunuh.

Dengan demikian, pembelajaran matematika dengan menggunakan model Advance Organizer dengan peta konsep diharapkan mampu untuk meningkatkan sikap positif siswa 
terhadap pelajaran matematika, sebab menurut Ruseffendi (2005), sikap positif terhadap matematika itu berkolerasi positif dengan prestasi. Yang dimaksud dengan sikap positif adalah sikap yang menyukai terhadap apa yang menjadi perhatian. Selaras dengan hal tersebut, Ruseffendi (2006) menyatakan bahwa sikap positif seorang siswa adalah dapat mengikuti pelajaran dengan sungguh-sungguh, dapat menyelesaikan tugas yang diberikan dengan baik, tuntas dan tepat waktu, berpartisipasi aktif, dan dapat merespon dengan baik tantangan yang diberikan.

Jadi, sikap memiliki dua arah yang berlawanan terhadap suatu objek, yaitu apakah setuju atau tidak setuju, apakah mendukung atau tidak mendukung terhadap suatu objek atau pernyataan.

Tujuan penelitian ini adalah untuk mengkaji tentang sikap siswa terhadap pembelajaran matematika yang memperoleh model pembelajaran Advance Organizer dengan peta konsep.

\section{METODE PENELITIAN}

Dalam penelitian ini metode yang digunakan adalah metode eksperimen. Ruseffendi (2005) menyatakan bahwa penelitian eksperimen atau percobaan (experimental research) adalah penelitian yang benar-benar untuk melihat hubungan sebab-akibat. Dalam penelitian ini perlakuan terhadap kelas eksperimen yaitu siswa yang memperoleh pembelajaran model Advance Organizer dengan peta konsep. Sedangkan kelas kontrol menggunakan pembelajaran ekspositori. Desain penelitian yang digunakan adalah desain kelompok kontrol tes awal-tes akhir. Dalam desain ini terdapat dua kelas yang dipilih secara acak menurut kelas, yaitu kelas kontrol dan kelas eksperimen. Kemudian kedua kelas tersebut diberi tes awal untuk mengetahui kemampuan awal antara kelas eksperimen dan kelas kontrol sebelum diberikan pembelajaran. Tes akhir dilakukan setelah proses pembelajaran berlangsung dengan tujuan untuk mengetahui sikap siswa setelah mengalami pembelajaran.

Menurut Ruseffendi (2005), gambar desainnya adalah sebagai berikut:

$\begin{array}{llll}\text { A } & \text { O } & \text { X } & \text { O } \\ \text { A } & \text { O } & & \text { O }\end{array}$

Keterangan:

A : Subjek yang dipilih secara acak menurut kelas

O : Tes awal (pretes) $=$ Tes akhir (postes) 
X : Perlakuan (dalam penelitian ini adalah pembelajaran model Advance Organizer dengan peta konsep)

Penelitian ini akan dilakukan di SMPN 1 Kroya, Indramayu. Dari beberapa kelas VII yang ada di SMP Negeri 1 Kroya, dipilih dua kelas yang kemudian dijadikan sampel. Instrumen yang digunakan dalam penelitian ini adalah tes dan non-tes. Dan instrumen tes yang digunakan adalah lembar wawancara dan angket.

\section{HASIL DAN PEMBAHASAN}

Tabel 1. Normalitas Distribusi Sikap

\begin{tabular}{rrrrrrrr}
\hline & \multicolumn{3}{c}{ Kolmogorov-Smirnov ${ }^{\text {a }}$} & \multicolumn{3}{c}{ Shapiro-Wilk } & \\
\hline & Statistic & df & Sig. & Statistic & df & Sig. \\
Nilai Sikap Siswa & .072 & 31 & $.200^{*}$ & .982 & & 31 & .855 \\
& & & & & & & \\
\hline
\end{tabular}

Tabel 2. Uji Satu Pihak

\section{Test Value $=3$}

95\% Confidence

Interval of the

Difference

\begin{tabular}{rrrrrrr} 
& \multicolumn{1}{c}{$\mathrm{T}$} & $\mathrm{df}$ & Sig. (2-tailed) & Mean Difference & \multicolumn{1}{c}{ Lower } & \multicolumn{1}{c}{ Upper } \\
Nilai & 66.719 & 30 & .000 & 110.194 & 106.82 & 113.57
\end{tabular}

Berdasarkan analisis data hasil penelitian, diperoleh bahwa sikap siswa terhadap pembelajaran matematika yang menggunakan model pembelajaran Advance Organizer dengan peta konsep lebih positif dibandingkan siswa yang menggunakan metode ekspositori. Hal ini disebabkan karena pada model pembelajaran Advance Organizer dengan peta konsep dapat memperkuat serta menstimulus semua sikap dan ketrampilan siswa. Sesuai dengan apa yang dinyatakan oleh Sudjana (Herdian, 2010), "Ada tiga komponen sikap yakni: kognisi, berkenaan dengan pengetahuan seseorang tentang objek atau stimulus yang dihadapinya. Afeksi, berkenaan dengan perasaan dalam menghadapi objek tersebut. Konasi, berkenaan dengan kecenderungan berbuat terhadap objek tersebut". Oleh karena itu, sikap selalu bermakna bila dihadapkan kepada objek tertentu, misalnya sikap siswa terhadap mata pelajaran, sikap mahasiswa terhadap pendidikan matematika atau sikap guru terhadap profesinya. Statistik parametris yang digunakan untuk menguji 
hipotesis deskriptif adalah t-test satu sampel dengan menggunakan rumus $\mathrm{t}$ dan diuji satu pihak yaitu pihak kanan.

Hipotesis yang diuji adalah sebagai berikut:

$\mathrm{H}_{0}$ : Sikap belajar matematika kelas eksperimen setelah dilakukan pembelajaran lebih kecil atau sama dengan dari skor netral skala sikap yaitu 3,00.

$\mathrm{H}_{1}$ : Sikap belajar matematika kelas eksperimen setelah dilakukan pembelajaran lebih besar dari skor netral skala sikap yaitu 3,00.

Pasangan hipotesis tersebut dapat dirumuskan dalam bentuk hipotesis statistik seperti berikut:

$$
\begin{aligned}
& \mathrm{H}_{0}: \mu_{0} \leq 3,00 \\
& \mathrm{H}_{1}: \mu_{0}>3,00
\end{aligned}
$$

Adapun cara pengolahannya dengan menggunakan One-Sample test dengan asumsi kedua varians sama (equal varians assumed) dengan taraf signifikannya 5\% dalam program SPSS 17.0 for windows. Menurut Santoso (Nuraine, 2011) kriteria uji kesamaan dua rerata adalah "Jika probabilitas $>0,05$, maka $\mathrm{H}_{0}$ diterima, sebaliknya jika probabilitas $<0,05$, maka $\mathrm{H}_{0}$ ditolak". Menurut Uyanto (2006), untuk uji satu pihak, digunakan setengah dari nilai signifikansinya.

\section{a) Uji normalitas}

Berdasarkan hasil perhitungan dengan uji statistik melalui program SPSS 17.0 for Windows dengan menggunakan uji Shapiro-Wilk nilai signifikan untuk data hasil nilai sikap siswa adalah 0,855. Nilai tersebut lebih dari 0,05 maka Ho diterima. Jadi data sikap siswa berasal dari populasi yang berdistribusi normal

\section{b) Melakukan uji satu pihak}

Dari One-Sampel Test terlihat bahwa nilai signifikansi dua pihaknya (Sig. 2Tailed) adalah 0,000. Untuk skala sikap menggunakan uji satu pihak, yaitu setengah dari

nilai signifikansinya, $\frac{0,000}{2}=0,000<0,05$. Nilai tersebut lebih kecil dari 0,05 sehingga berdasarkan kriteria pengujian, $\mathrm{H}_{0}$ ditolak. Maka dapat disimpulkan bahwa sikap siswa positif terhadap pelajaran matematika, pembelajaran matematika menggunakan model Advance Organizer dengan peta konsep. 
Berdasarkan data penelitian dan analisis data serta pengujian hipotesis dalam penelitian ini, maka dapat disimpulkan bahwa: sikap siswa positif terhadap penggunaan model Advance Organizer dengan peta konsep dalam pembelajaran matematika.

\section{KESIMPULAN}

Berdasarkan data penelitian dan analisis data serta pengujian hipotesis dalam penelitian ini, maka dapat disimpulkan bahwa, sikap siswa positif terhadap penggunaan model Advance Organizer dengan peta konsep dalam pembelajaran matematika. Untuk menindaklanjuti hasil penelitian ini, diharapkan pada penelitian selanjutnya untuk meneliti tentang sikap siswa berdasarkan gender atau KAM.

\section{DAFTAR PUSTAKA}

Dahar, R. W. (2011). Teori-Teori Belajar dan Pembelajaran. Jakarta: Erlangga.

Gintings, A. (2008). Esensi Praktis Belajar dan Pembelajaran. Bandung: Humaniora.

Herdian. (2010). Kemampuan Pemahaman Matematika. [Online] Tersedia: http://herdy07.wordpress.com/2010/05/27/kemampuan-pemahaman-matematis/ $\quad[12$ Desember 2016].

Nuraine, I. (2011). Pengaruh Model Pembelajaran Auditory, Intellectually And Repetition (AIR) terhadap Kemampuan Komunikasi Matematika Siswa SMK. Skripsi pada UNPAS Bandung: Tidak Diterbitkan.

Ruseffendi, E.T. (2005). Dasar-Dasar Penelitian Pendidikan \& Bidang Non-Eksakta Lainnya. Bandung: Tarsito.

Ruseffendi, E.T. (2006). Pengantar kepada Membantu Guru Mengembangkan Kompetensinya dalam Pengajaran Matematika untuk Meningkatkan CBSA. Bandung: Tarsito.

Suherman, E, dkk. (2001). Strategi Pembelajaran MAtematika Kontemporer. Bandung: JICA.

Suherman \& Sukjaya .(1990). Evaluasi Pendidikan Matematika. Bandung: Wijayakusuma.

Supratman. (2009). Meningkatkan Kemampuan Pemecahan Masalah Matematika Melalui Pembelajaran dengan Peta Konsep. Tesis pada PPS UPI. Bandung: Tidak Diterbitkan

Sutrisno, Edy. (2011). Manajemen Sumber Daya Manusia. Jakarta: Kencana Prenada Media Grup.

Syah, M. (2007). Psikologi Pendidikan dengan Pendekatan Baru. Bandung: PT Remaja Rosdakarya.

Uyanto, S.S. (2006). Pedoman Analisis Data dengan SPSS. Yogyakarta: Graha Ilmu.

Widiastuti. (2010). Pengaruh Pembelajaran Model Eliciting Activities (MEAs) terhadap Kemampuan Representasi Matematis dan Self Efficacy Siswa. Tesis pada SPS UPI Bandung: Tidak Diterbitkan. 